\title{
A SHORT REVIEW OFTHE PREVIOUS AND CURRENT EPIDEMIOLOGICAL SITUATION OF SCHISTOSOMIASIS IN CHINA
}

\begin{abstract}
Cen Li-ping
Schistosomiasis japonica has long been endemic in the People's Republic of China. In the 1950s, the number of the infected persons was estimated at 10 million; infected snail habitats were estimated at more than 14 billion square metres and infected cattle at 1.2 million. After schistosomiasis control measures were carried out, it was a great success. According to the survey of 1989, infected persons were estimated at 0.95 million; infected snails at 3.47 billion and infected cattle at about 0.1 million. These results compared with those of the 1950 s show big reductions in prevalence rates $90.5 \%$, $75.2 \%$ and $91.6 \%$, respectively. At present, the disease is a threat in the marshland and lake regions and the high mountainous regions. To maintain the success achieved in effective control and to bring the yet endemic marshland and lake regions and mountainous areas under control are hard and long-term tasks confronting the People's Republic of China.
\end{abstract}

Key-words: Schistosomiasis. Control. Epidemiology.

Schistosomiasis, a world parasitic disease, affects more than 200 million people, about 70 million of them infected with Schistosoma mansoni, the others being infected with $S$. japonicum, S. haematobium, S. intercalatum, S. mekongi and S. malayensis ${ }^{611}$. The control of schistosomiasis is one of the most difficult tasks facing public health services in affected countries, because of the world-wide spread of the intermediate snail host and escape mechanisms in relation to existing control methods as well, the frequency of human contact with contaminated water are almost unavoidable. The lack appropriate sanitation and potable water supply for human populations and the limitations of individual and mass treatment among others are obvious control retarding factors. Therefore, schistosomiasis control has to be maintained at long term ${ }^{511}$.

Epidemiological situation of China. Schistosomiasis japonica has long been endemic in the People's Republic of China. The disease has a devastating effect on rural areas and people's health. In the 1950s, the population at risk of infection was more than 100 million and the infected persons were

Address to: Dra Cen Li-ping. Hubei Institute of Schistosomiasis Control. Wuchang Zhuodaoquan 430070, Wuhan, Hubei, People's Republic of China.

Recebido para publicação em 21/03/96. estimated at 10 million; Oncomelania snail habitats were estimated at more than 14 billion square metres; the number of infected cattle was about 1.2 million. A considerable number of acute infection appeared per year, and many people were killed due to $S$. japonicum ${ }^{129}$.

After intensive work on schistosomiasis control for more than three decades, China has achieved great success in this domain. According to survey data of 1989, infected persons were estimated at 0.95 million; the infected snails area was estimated at 3.47 billion $\mathrm{m}^{2}$; while infected cattle about 0.1 million $^{3}$. These results compared with those of the 1950s' show a big reduction in prevalence rates of $90.5 \%, 75.2 \%$ and $91.6 \%$, respectively (Table 1).

\begin{tabular}{llccc}
\multicolumn{4}{l}{ Table 1 - Persons, cattle and snail infection in million. } \\
\hline Subjects & Unit & 1963 & 1989 & $\begin{array}{c}\text { Reduction } \\
\text { rate } \%\end{array}$ \\
\hline Infected persons & cases & 10 & 0.95 & 90.5 \\
Infected cattle & cases & 1.2 & 0.1 & 91.67 \\
Infected snails & $\mathrm{m}^{2}$ & 14000 & 3470 & 75.21
\end{tabular}

Geographical distribution of schistosomiasis. Based upon the epidemiological pattern of schistosomiasis and ecological characteristics of the snail vectors, three types of endemic areas has been stratified: plain regions, mountainous regions and marshland and lake regions. In China, endemic areas are along the 
Li-ping C. A short review of the previous and current epidemiological situation of schistosomiasis in China. Revista da Sociedade Brasileira de Medicina Tropical 30:57-60, jan-fev, 1997.

Yangtze River and extend southward to include 10 provinces in the 1950s. As much as $82.8 \%$ of snail habitats were in the marshland and lake region, $9.6 \%$ in the mountainous areas and $7.6 \%$ in the plain regions. The distribution of infected persons in the three regions was $43.7 \%, 22.7 \%$ and $33.6 \%$ respectively ${ }^{8}$. After three decade's efforts, the distribution of infected persons and snails changed dramatically. The results of the survey in 1989 indicated that $95.5 \%$ of snail habitats were in the marshland and lake regions, 3.9\% in the mountainous areas and only $0.6 \%$ in the plain regions ${ }^{14}$ (Figure 1). The distribution of infected persons was $85.6 \%$ in the marshland and plain regions, but the mountainous had only $14.4 \%$ of the total number of infected persons in $1991^{14}$ (Figure 2).

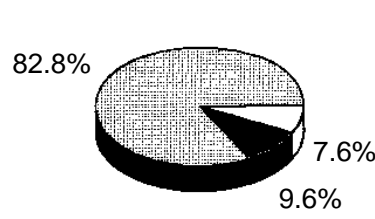

1963

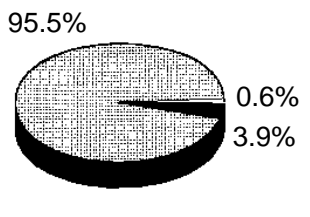

1989

\section{Marshlands $\square$ Mountains $\square$ Plains}

Figure 1 - The snails distribution proportion at different endemic areas of China.
The survey data showed the schistosomiasis endemic areas in China, as being the marshland and lake regions and high mountainous areas mainly. The marshland and lake regions cover a vast area enylobing five provinces along the Yangtze River. These are: Huhan, Hubei, Jiangxi, Jiangsu and Anhui province. These areas due to silt deposits forming islets, spand river beaches thus promoting weed growth. In some areas, large sheet of reeds and willow trees are planted, which are all very suitable for snail breeding. On the other hand, the population density is high and their agricultural and daily activities force people in contact with the contaminated water and large number of infected cattle contribute to a high level of contamination. Furthermore, migratory fishermen and boatmen who usually have high infection,
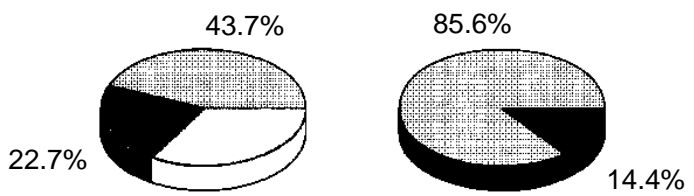

$33.6 \%$

1963

1989 and practice indiscriminate defecation, contribute to high transmission of $S$. japonicum. Compliance for stool examination and treatment in these communities is usually poor ${ }^{4}$.

Mountainous region, mainly in Sichuan and Yuannan provinces, pose another problem. The population density in these areas is quite low but the snail habitats are extensive. This regions are socioeconomically underdeveloped and difficult to get access to. The snail control in these areas are impractical, and even chemotherapy is not easy because of poor accessibility ${ }^{1}$.

Control strategies. This paper does not discuss administrative measures in schistosomiasis control, but just the technical strategies. The goal of schistosomiasis control in China is to

reduce schistosomiasis in all the amenable areas and to interrupt the transmission ${ }^{14}$. The different control strategies have been carried out in the different prevalence rate of the endemic areas in China.

Chemotherapy: Schistosomiasis control in China based on the large-scale chemotherapy have been tried for persons and cattle. Chemotherapy plays the most important role in both infection and disease control. Mass treatment can rapidly reduce morbidity in a short term ${ }^{10}$ but as a single measure, no matter how frequently it is given will hardly reach the target of transmission control ${ }^{4}$. If only chemotherapy alone was applied, infection rate can be reduced, but may be rise again after a short period. In addition, subsequent transmission and reinfection frequently occurs 
Li-ping C. A short review of the previous and current epidemiological situation of schistosomiasis in China. Revista da Sociedade Brasileira de Medicina Tropical 30:57-60, jan-fev, 1997.

after the population come in contact with contaminated water.

Combination of chemotherapy and elimination of snails: The mollusciciding is an important adjunct to chemotherapy and other methods in many endemic situations. Selective population chemotherapy plus focal elimination of snail in susceptible zones is relatively effective for interrupting transmission, but is much expensive ${ }^{13}$. The control of snail intermediate host is an effective means of reducing transmission of schistosomiasis, and may entail the use of chemical molluscicides, plant molluscicides, biological agents and environmental management. The efficacy of snail control can be enhanced if combined with other control methods.

Multidisciplinary strategy: These include health education, management of stool and water, environment and individual protection as well as water supply and sanitation. Education, information and communication strategies in control programs should be carried out, not only to bring about specific changes in behavior aiming at disease prevention but also to stimulate community participation in health programs. Although sanitation and water supply have always been pointed out as fundamental prophylactic measures to eliminate the disease, they have actually never been extensively and continuously carried out. Schistosomiasis is related to poor life conditions in areas lacking basic services and with a very poor source of income. For each strategy, it is very important to maintain a continuos process of evaluation, paying attention to the baseline data that is collected before the implementation of the new measures. This evaluation system contributes to the necessary changes or improvements of the program in order to reach the planned objective. Water supply and sanitation in some endemic areas have been improved and the onset of a large number of schistosomiasis consequently prevented ${ }^{7}$.

The strategy for morbidity control is effective as demonstrated by survey data in China ${ }^{12}$. According to WHO (1993) many factors should be observed when developing schistosomiasis control strategies: the felt needs of the population, the species of schistosoma present; the prevalence and intensity of infection, and the prevalence and severity of morbidity; epidemiological, ecological and environmental characteristics; the facilities of primary health care; technical support and the capacity for control and strict management of the general coordination.

Although schistosomiasis control has achieved great success in China, the endemic areas are still very large, and morbidity due to the disease have been rising in some places, mainly in marshland and lake regions and high mountainous areas. Therefore, the areas of the successful control should be strengthened. On the other hand, the quality of control measures which were carried out should be maintained. Now the project on the control of schistosomiasis supported by the World Bank Loan is an important part of the integrated program of schistosomiasis control in China. It is beneficial in accelerating schistosomiasis control.

\section{RESUMO}

A esquistossomose japonica, há séculos, é considerada endêmica na República Popular da China. Em 1950, estimou-se em 10 milhões o número de pessoas infectadas; focos de caramujos infectados ocupavam 14 bilhões de metros quadrados e era de 1,2 milhões o número de gado infectado. As medidas de controle da esquistossomose alcançaram grande sucesso. De acordo com o levantamento realizado em 1989, o número de pessoas infectadas decresceu para 950 mil, focos de caramujos infectados ocupavam 3,47 bilhões de metros quadrados e o número de gado contaminado passou a $100 \mathrm{mil}$. Estes resultados, quando comparados ao de 1950, mostraram grande redução, sendo de respectivamente, 90,5\%, 75,2\% e 91,6\%. Atualmente, a endemia está presente nas áreas pantanosas, em lagos e nas regiões montanhosas. A manutenção do sucesso obtido e o controle efetivo nas áreas ainda endêmicas é um desafio que exigirá trabalho árduo e a longo prazo na República Popular da China.

Palavras-chaves: Esquistossomose. Controle. Epidemiologia.

\section{ACKNOWLEDGMENTS}

This report was made when Cen Li-ping was engaged in advanced studies for schistosomiasis control in Centro de Pesquisas René Rachou Minas Gerais, Brazil, under the direction of Dr. Naftale Katz.

\section{REFERENCES}

1. Anonymous. Schistosomiasis control: China Wkly. Epidemiology Record 63:42-47, 1988a. 
Li-ping C. A short review of the previous and current epidemiological situation of schistosomiasis in China. Revista da Sociedade Brasileira de Medicina Tropical 30:57-60, jan-fev, 1997.

2. Anonymous. Schistosomiasis control: A review of national control programs in the Western Pacific Region. Wkly. Epidemiology Record 3:209. 215, 1988b.

3. Anonymous. Schistosomiasis Advisory Committee, Ministry of Public Health. Analysis on epidemiological situation of schistosomiasis in 1988 in China. Chinese Journal of Schistosomiasis Control 1:5-12,1989.

4. Chen MG. Schistosomiasis control program in the People's Republic of China: A review. Southeast Asian Journal of Tropical Medicine and Public Health 20:511-517, 1989.

5. Coura JR. Control of schistosomiasis in Brazil: Perspectives and Proposals. Memórias do Instituto Oswaldo Cruz 90:257-260, 1995.

6. Katz N. Chemotherapy of Schistosomiasis mansoni. Advances in Pharmacology and Chemotherapy 14:1-70, 1977

7. Mao SB. The object, technical measurement and research in control of Schistosomiasis. Chinese Journal of Schistosomiasis Control 2:1-5, 1990.

8. Mao SB, Shao BR. Schistosomiasis control in the People's Republic of China.The American Society of Tropical Medicine and Hygiene 31:92-99, 1982.
9. Qian SZ, Lu G, Mao SB, Zheng G. Schistosomiasis atlas in the People's Republic of China. Shanghai:Chinese Map Society p. 64,1985.

10. Wang ZH, Zhang JW, Yi ZH, Gao SN. Study on the eliminating infectious source for interrupting transmission in lake regions. Chinese Journal of Schistosomiasis Control 2:17-19,1990.

11. World Health Organization. The control of schistosomiasis:Second report of the WHO Expert Committee. Technical Report. Series 830, Geneva 1993.

12. World Health Organization. The control of schistosomiasis:Technical Report. Series 830, 1994.

13. Yi ZH, Wang ZH, Cen LP. The comparison of different schemes of chemotherapy for schistosomiasis control. Chinese Journal of Parasitic Diseases Control 6:32-35, 1993.

14. Yuan HC. Schistosomiasis control in China. Memórias do Instituto Oswaldo Cruz 90:297-301, 1995. 